\title{
ANALISIS STRATEGI PENGEMBANGAN INDUSTRI JAMU TRADISIONAL DI KABUPATEN BANGKALAN
}

\author{
Risa Dewi Munica, Millatul Ulya dan Muhammad Fakhry \\ Program Studi Teknologi Industri Pertanian \\ Fakultas Pertanian Universitas Trunojoyo Madura \\ Jl. Raya Telang, Kecamatan Kamal, Bangkalan, Madura 69162 \\ E-mail : millatul.utm@gmail.com
}

\begin{abstract}
Data of Disperindag Bangkalan Regency (2015), shows that Bangkalan Regency has 20 herbal medicine industries. After doing research survey there are some herbal medicine industries that have been inactive, so that this research is conducted to find out alternative strategy that can be used as an effort to develop herbal medicine industry in Bangkalan Regency. This research used analysis of internal environment (IFE) and external (EFE), External-internal matrix (IE), SWOT and QSPM matrix (Quantitative Strategic Planning Matrix). There are 16 internal factors and 11 external factors. As for alternative strategy there are 5 alternatives obtained from SWOT matrix and IE matrix. In the QSPM matrix, the priority of strategy is 1. Maintain and improve product quality, 2. Increase promotional activities and expand the marketing area,3. Improving relationships with government and other agencies, 4. Maintain company image, and 5. Develop cooperation with other industries outside the region.
\end{abstract}

Keywords : Herbal Medicine, Development Strategy, IE, SWOT and QSPM.

\begin{abstract}
ABSTRAK
Data Disperindag Kabupaten Bangkalan (2015), menunjukkan bahwa Kabupaten Bangkalan memiliki 20 industri jamu. Setelah dilakukan survey penelitian ada beberapa industri jamu yang sudah tidak aktif, sehingga penelitian ini dilakukan untuk mengetahui alternatif strategi yang dapat digunakan sebagai upaya pengembangan industri jamu di Kabupaten Bangkalan. Analisis yang digunakan dalam penelitian ini adalah analisis lingkungan internal (IFE) dan eksternal (EFE), matrik internal eksternal (IE), matrik SWOT dan QSPM (Quantitative Strategic Planning Matriks ). Dari hasil analisis diperoleh ada 16 faktor internal dan 11 faktor eksternal. Sedangkan untuk alternatif strategi ada 5 alternatif yang diperoleh dari matrik SWOT dan matrik IE. Pada matrik QSPM diperoleh prioritas strategi adalah 1. Mempertahankan dan meningkatkan kualitas produk, 2. Meningkatkan kegiatan promosi dan memperluas daerah pemasaran, 3. Meningkatkan hubungan dengan pemerintah maupun lembaga lain, 4. Mempertahankan citralimage perusahaan, dan 5. Mengembangkan kerjasama dengan indsutri lain diluar wilayah.
\end{abstract}

Kata Kunci : Jamu, Strategi Pengembangan, IE, SWOT dan QSPM.

\section{PENGAHULUAN}

Jamu merupakan obat yang berasal dari bahan tumbuh-tumbuhan, hewan dan mineral atau kombinasi dari ketiganya (Geertz 1981). Menurut Pali (1994) jamu dinilai sangat bermanfaat untuk segala macam penyakit dan juga sebagai pemeliharaan kesehatan tubuh.

Madura merupakan pulau yang memiliki banyak sekali industri atau usaha kecil menengah (UKM) produk jamu.

Menurut Dinas Perizinan dan Perdagangan Kabupaten Bangkalan tahun 
(2015), Kabupaten Bangkalan memiliki 20 industri penghasil jamu yang tersebar di seluruh daerah Kabupaten Bangkalan. Setelah dilakukan penelitian pendahuluan, sebesar $50 \%$ perusahaan jamu sudah tidak aktif karena disebabkan oleh beberapa faktor. Faktor tersebut diantaranya adalah tidak adanya generasi penerus industri, keterbatasan modal yang dimiliki dan lain sebagainya.

Manajemen strategi merupakan sejumlah keputusan dan tindakan yang mengarah pada penyusunan suatu strategi atau sejumlah strategi yang efektif untuk membantu mencapai sasaran perusahaan. Salah satu metode untuk merumuskan strategi yang efektif adalah metode SWOT karena dapat menggambarkan kondisi internal dan eksternal perusahaan dilanjutkan dengan QSPM (Quantitative strategic planning matrik) untuk menentukan prioritas strategi berdasarkan tingkat kepentingan faktor internal dan eksternal.

(Jauch dan Gluek 1988). Perencanaan strategi diperlukan untuk industri-industri jamu di Kabupaten Bangkalan sebagai upaya menghindari adanya penurunan jumlah produksi dan jumlah industri jamu di Kabupaten Bangkalan.

Dengan adanya analisis mengenai kondisi obyektif faktor internal dan eksternal yang dimiliki oleh industri jamu di Kabupaten Bangkalan, maka penelitian ini bertujuan untuk mengetahui alternatif strategi serta prioritas strategi yang dapat digunakan sebagai upaya pengembangan industri-industri jamu di Kabupaten Bangkalan.

\section{METODE}

\section{Tempat Penelitian}

Penelitian ini dilakukan di industriindustri jamu di Kabupaten Bangkalan, pengambilan data dilakukan pada bulan Maret 2017.

\section{Teknik Pengumpulan Data}

Pengumpulan data dilakukan dengan cara kuisoner, wawancara, observasi, diskusi, studi pustaka baik dengan jurnal, buku, dan artikel yang berhubungan dengan penelitian.

\section{Metode Penentuan Sampel}

Metode penentuan sampel yang digunakan adalah non probability sampling yaitu dengan menggunakan metode purposive sampling. Responden penelitian ini berjumlah 8 orang.

\section{Metode Pengolahan dan Analisis Data}

Menurut David (2009) tahapan perencanaan strategi dilakukan dengan melalui tiga tahapan analisis, yaitu: tahap masukan (The Input Stage), tahap pencocokan (The Matching Stage), dan tahap keputusan (The Decision Stage).

\section{Tahap Pemasukan (The Input Stage)}

Pada tahap ini dilakukan identifikasi terhadap faktor-faktor internal maupun eksternal industri-industri jamu di Kabupaten Bangkalan. Dalam penelitian ini, tahap input menggunakan matrik EFE dan IFE. Penentuan bobot dilakukan dengan skala menggunakan metode paired comparison (Nurmagribah 2006). Skalanya adalah sebagai berikut : $1=$ Jika indikator horizontal kurang penting daripada indikator vertikal, 2 = Jika indikator horizontal sama penting dengan indikator vertikal, 3 = jika indikator horizontal lebih penting daripada indikator vertikal.

\section{Tahap Pencocokan (The Matching Stage)}

Pada tahap pencocokan dilakukan dengan menggunakan matrik SWOT dan IE (Internal-Eksternal). Matriks IE berguna untuk menampilkan posisi perusahaan dalam diagram skematis atau disebut juga sebagai matriks portofolio. Analisis SWOT digunakan untuk memaksimalkan kekuatan (Strengths) dan peluang (Opportunities), namun secara 
bersamaan dapat meminimalkan kelemahan (Weaknesses) dan ancaman (Threats).

\section{Tahap Pengambilan Keputusan (The Decision Stage)}

Tahapan terakhir adalah melakukan tahapan pengambilan keputusan (decision stage) yang akan menyusun daftar prioritas strategi yang harus diimplementasikan. Menurut David (2009) matrik perencanaan strategi kuantitaif Quantitative strategic planning matrik (QSPM) adalah alat yang memungkinkan para penyusun strategi mengevaluasi hasil berbagai strategi alternatif secara obyektif berdasarkan faktor-faktor keberhasilan penting eksternal dan internal. Penentuan nilai daya tarik (Attractiveness Scores - AS) dengan menggunakan skala sebagai berikut : $1=$ tidak menarik, $2=$ agak menarik, 3 = cukup menarik, $4=$ sangat menarik.

\section{HASIL DAN PEMBAHASAN}

\section{Identitas Responden}

Identitas responden merupakan gambaran umum tentang keadaan responden yang meliputi nama, tanggal lahir, umur, alamat, pekerjaan, dan no hp. Responden ada
8 orang, 6 selaku pemilik industri jamu dan 2 responden yang merupakan responden ahli yang berasal dari ketua paguyuban industri jamu Kabupaten Bangkalan dan Pegawai Dinas Perindustrian dan Ketenagakerjaan.

\section{Kegiatan Industri Jamu}

Bahan baku yang diperoleh industri jamu merupakan bahan baku yang mayoritas berasal dari petani lokal. Berikut merupakan Kegiatan industri jamu yang meliputi:

1. Penyortiran

2. Peracikan setelah bahab baku bersih dan kering

3. Pengeringan singkat

4. Penggilingan bahan baku

5. Proses pengayakan

6. Proses pencampuran

7. Pengemasan / tahapan selanjutnya

\section{Jumlah Produksi Jamu}

Jumlah rata-rata produksi industriindustri jamu di Kabupaten Bangkalan disesuaikan dengan kebutuhan atau kapasitas permintaan konsumen dan jumlah jenis jamu yang diproduksi pada masing-masing industri. Data rata-rata jumlah produksi setiap industri jamu dapat dilihat pada Tabel 1.

Tabel 1. Rata-Rata Produksi Jamu

\begin{tabular}{llc}
\hline No & \multicolumn{1}{c}{ Nama Industri } & Rata-Rata Produksi \\
\hline 1 & Jamu Tresna & $3-4 \mathrm{~kg}$ \\
2 & Jamu Sari Dewi & $14.000 \mathrm{ml}$ \\
3 & Jamu Sehat Alifah & $7 \mathrm{~kg}$ \\
4 & Jamu Firdaus & $5 \mathrm{~kg}$ \\
5 & Jamu Ribkah Maryam Jokotole & $5 \mathrm{~kg}$ \\
6 & UD. Nata Payung Emas & $5 \mathrm{Kg}$ \\
\hline
\end{tabular}

\section{Identifikasi Faktor Strategi}

Identifikasi pada faktor strategi dilakukan dengan cara menganalisis data sekunder yang berupa hasil wawancara dengan 6 pemilik industri jamu di Kabupaten Bangkalan dan juga kuisoner dengan 2 pakar yang merupakan ketua paguyuban industri jamu Kabupaten Bangkalan dan pegawai
Dinas Perindustrian dan Ketenagakerjaan yang nantinya data tersebut digunakan untuk mencari faktor-faktor internal dan juga eksternal yang meliputi kekuatan, kelemahan, peluang dan juga ancaman. Pada faktor internal digolongkan menjadi faktor manajemen, pemasaran, keuangan, produksi dan juga sumber daya manusia. Sedangkan 
faktor eksternal meliputi faktor ekonomi, 2 merupakan hasil perumusan dan sosial, budaya, demografi, lingkungan, pembobotan faktor internal dan eksternal : pemerintah, teknologi dan kompetitor. Tabel

Tabel 2. Analisis Matrik IFAS (Internal Factors Analysis Summary)

\section{Faktor-Faktor Internal}

Kekuatan/Stenght (S)

1. Kepemimpinan yang berpandangan kedepan

2. Potensi SDA yang dimiliki

3. Reputasi perusahaan

4. Sudah adanya konsumen tetap

5. Kualitas produk terjamin

6. Kualitas pelayanan baik

7. Produk yang beragam

8. Efektivitas penetapan harga

9. Tingkat higienis terjamin

10.Tidak adanya bahan pengawet

11. Keahlian dalam meracik jamu

Kelemahan/Weakness (W) :

1. Tenaga pemasaran terbatas

2. Efektivitas kegiatan promosi

3. Biaya / keterbatasan modal

4. Stabilitas keuangan

5. Kemampuan pengusaha jamu terbatas

\section{Bobot Rating Bobot $x$ Rating}

\begin{tabular}{lll}
0,087 & 4 & 0,348 \\
0,072 & 3 & 0,217 \\
0,039 & 3 & 0,118 \\
0,060 & 4 & 0,240 \\
0,064 & 3 & 0,193 \\
0,058 & 3 & 0,174 \\
0,041 & 3 & 0,124 \\
0,068 & 3 & 0,205 \\
0,058 & 4 & 0,232 \\
0,052 & 4 & 0,207 \\
0,081 & 4 & 0,323 \\
& & \\
0,062 & 1 & 0,062 \\
0,052 & 2 & 0,104 \\
0,075 & 1 & 0,075 \\
0,072 & 1 & 0,072 \\
0,058 & 2 & 0,116 \\
\hline 1,000 & & 2,810 \\
\hline
\end{tabular}

Dari hasil analisis matrik IFAS (Internal Factors Analysis Summary) dapat dijelaskan bahwa dari 16 faktor yang teridentifikasi pada faktor internal, faktor tersebut tergolong menjadi dua faktor yaitu merupakan 11 faktor kekuatan dan 5 faktor kelemahan.

Pada faktor kekuatan nilai pembobotan tertinggi yaitu pada faktor kepemimpinan yang berpandangan kedepan memiliki nilai pembobotan sebesar 0,348,. Sedangkan pada faktor kelemahan faktor yang memiliki nilai tertinggi adalah faktor kemampuan pengusaha jamu terbatas dengan nilai pembobotan sebesar 0,116 . Keseluruhan nilai total bobot kali rating pada faktor internal adalah sebesar 2,810 .
Dari hasil analisis matrik EFAS (Tabel 3) (Eksternal Factors Analysis Summary) dapat dijelaskan bahwa ada 11 faktor eksternal yang teridentifikasi, faktor tersebut tergolong menjadi 2 faktor yaitu sebagai 5 faktor peluang dan 6 faktor ancaman.

Peluang terbesar untuk industri-industri jamu di Kabupaten Bangkalan adalah faktor pertumbuhan ekonomi dengan nilai pembobotan sebesar 0,420, Sedangkan untuk faktor ancaman yang menjadi ancaman terbesar adalah faktor perijinan sulit dengan nilai pembobotan sebesar 0,210. Keseluruhan total nilai bobot kali ratingnya adalah 2,610 untuk faktor eksternal. 
Tabel 3. Analisis Matrik EFAS (Eksternal Factors Analysis Summary)

\begin{tabular}{lccc}
\hline \multicolumn{1}{c}{ Faktor-Faktor Eksternal } & Bobot & Rating & $\begin{array}{c}\text { Bobot x } \\
\text { Rating }\end{array}$ \\
\hline Peluang/Opportunities (O) : & & & \\
1. Pertumbuhan ekonomi & 0,105 & 4 & 0,420 \\
2. Perubahan gaya hidup & 0,077 & 4 & 0,308 \\
3. Dibentuknya paguyupan yang menaungi industi jamu & 0,086 & 4 & 0,344 \\
4. Perekembangan teknologi untuk pemasaran & 0,091 & 3 & 0,273 \\
5. Perkembangan teknologi pengolahan & 0,095 & 3 & 0,285 \\
Ancaman/ Threats (T) : & & & \\
1. Kenaikan tarif listrik, telepon, dan BBM & 0,100 & 2 & 0,200 \\
2. Perubahan harga bahan baku & 0,091 & 2 & 0,182 \\
3. Perijinan sulit & 0,105 & 2 & 0,210 \\
4. Perhatian pemerintah terhadap pengembangan industri & 0,114 & 1 & 0,114 \\
jamu & & & \\
5. Daya saing yang tinggi & 0,082 & 2 & 0,164 \\
6. Munculnya produk sejenis & 0,055 & 2 & 0,110 \\
Total & 1,000 & & 2,610 \\
\hline
\end{tabular}

\section{Analisis Matriks IE (Internal-Eksternal)}

Analisis matrik IE (Internal-Eksternal) diperoleh dari hasil analisis matrik IFAS dan matrik EFAS. Matrik IE merupakan suatu gambaran letak pemetaan antara skor total IFAS dan skor total EFAS.

Tabel 4. Analisis Matrik IE (Internal-Eksternal)

\section{Total Nilai IFAS}

\begin{tabular}{|c|c|c|c|c|}
\hline$y_{1}^{2}$ & & $\begin{array}{c}\text { Tinggi } \\
(3.0-4.0)\end{array}$ & $\begin{array}{c}\text { Sedang } \\
(2.0-2.99)\end{array}$ & $\begin{array}{c}\text { Rendah } \\
(1.0-1.99)\end{array}$ \\
\hline 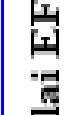 & $\begin{array}{c}\text { Tinggi } \\
(3.0-4.0)\end{array}$ & I & II & III \\
\hline $\begin{array}{l}\text { 茫 } \\
\text { त् }\end{array}$ & $\begin{array}{c}\text { Sedang } \\
(2.0-2.99)\end{array}$ & IV & V & VI \\
\hline$\stackrel{\stackrel{\circ}{\oplus}}{\circ}$ & $\begin{array}{c}\text { Rendah } \\
(1.0-1.99)\end{array}$ & VII & VIII & IX \\
\hline
\end{tabular}

Berdasarkan dengan total skor nilai IFAS sebesar 2,810 dan total skor nilai EFAS sebesar 2,610 maka matrik IE (InternalEksternal) industri jamu di Kabupaten Bangkalan berada pada koordinat $\mathrm{V}$, yang menunjukkan bahwa industri-industri jamu di Kabupaten Bangkalan bernilai rata-rata atau sedang. Sehingga strategi yang tepat digunakan sebagai pengembangan industri jamu di Kabupaten Bangkalan adalah strategi penetrasi pasar dan pengembangan produk.

\section{Analisis Matrik SWOT}

Pemilihan alternatif strategi dilakukan setelah industri mengetahui terlebih dahulu posisi industri jamu di Kabupetan Bangkalan 
sekarang berada pada kuadran mana dari ke-4

diagram posisi analisis SWOT dapat dilihat kuadran yang tersedia. Posisi industri-industri pada Gambar 1 sebagai berikut: jamu di Kabupaten Bangkalan menurut

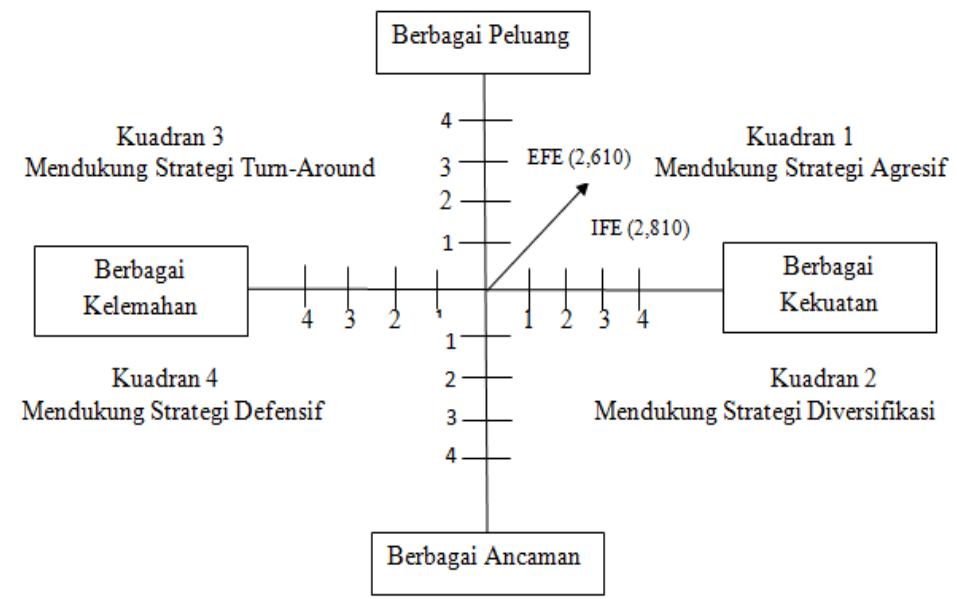

Gambar 1. Diagram Analisis SWOT

Diagram analisis SWOT pada Gambar 1 menunjukan bahwa industriindustri jamu di Kabupaten Bangkalan berada pada posisi kuadran 1 yang berarti bahwa pada situasi yang sangat menguntungkan. Strategi yang diterapkan pada kondisi ini adalah strategi yang mendukung dengan kebijakan pertumbuhan yang agresif.

Berdasarkan dengan analisis matrik SWOT yang telah dilakukan, maka dirumuskan beberapa strategi yang dapat diterapkan pada industri-industri jamu di Kabupaten Bangkalan sebagai upaya pengembangan industri jamu adalah sebagai berikut :

a. Strategi S-O (Strengths-Oppurtunities)

1. Mempertahankan dan meningkatkan kualitas produk

2. Mempertahankan image/citra perusahaan

b. Strategi W-O (Weaknesess Oppurtunities)

1. Meningkatkan kegiatan promosi dan memperluas daerah pemasaran
2. Mengembangkan kerja sama dengan industri lain diluar wilayah

c. Strategi S-T (Strengths - Threats)

1. Mempertahankan dan meningkatkan kualitas produk

2. Mempertahankan citra/image perusahaan

3. Meningkatkan hubungan dengan pemerintah maupun lembaga lain

d. Strategi W-T (Weaknesess - Threats)

1. Meningkatkan kegiatan promosi dan memperluas daerah pemasaran

2. Meningkatkan hubungan dengan pemerintah maupun lembaga lain

\section{Analisis QSPM (Quantitative Strategic Planning Matrix)}

Analisis matrik QSPM merupakan analisis strategi prioritas dari strategi yang telah didapatkan dari matrik SWOT.Dari matrik SWOT terdapat 5 strategi yang dapat diterapkan oleh industri-industri jamu di Kabupaten Bangkalan. 
Tabel 5. Analisis QSPM (Quantitative Strategic Planning Matriks)

\begin{tabular}{lccccc}
\hline & \multicolumn{5}{c}{ Alternatif Strategi } \\
\cline { 2 - 6 } QSPM Faktor Internal & Strategi 1 & Strategi 2 & Strategi 3 & Stretagi 4 & Strategi 5 \\
\cline { 2 - 6 } QSPM Faktor Eksternal & 2,742 & 2,426 & 2,589 & 2,394 & 2,458 \\
Total & 2,693 & 2,511 & 2,78 & 2,475 & 2,894 \\
& $\mathbf{5 , 4 3 5}$ & $\mathbf{4 , 9 3 7}$ & $\mathbf{5 , 3 6 9}$ & $\mathbf{4 , 8 6 9}$ & $\mathbf{5 , 3 5 2}$ \\
\hline
\end{tabular}

Dari hasil analisis matriks QSPM (Quantitative Strategic Planning Matrix) didapatkan hasil bahwa dari 5 strategi yang dirumuskanurutan prioritas strateginya adalah sebagai berikut :

1. Strategi mempertahankan dan meningkatkan kualitas produk dengan total nilai daya tarik sebesar 5,435

2. Strategi meningkatkan kegiatan promosi dan memperluas daerah pemasaran dengan total nilai daya tarik sebesar 5,369

3. Strategi meningkatkan hubungan dengan pemerintah maupun lembaga lain dengan total nilai daya tarik sebesar 5,352

4. Strategi mempertahankan citra/image perusahaan dengan total nilai daya tarik sebesar 4,937

5. Strategi mengembangkan kerja sama dengan industri lain diluar wilayah dengan total nilai daya tarik sebesar 4,869

\section{KESIMPULAN}

Berdasarkan hasil dan pembahasan, dapat disimpulkan bahwa:

1. Faktor internal industri jamu di Kabupaten Bangkalan meliputi manajemen perusahaan, pemasaran, keuangan, produksi dan sumber daya manusia.

2. Faktor eksternal industri jamu di Kabupaten Bangkalan meliputi ekonomi, kondisi sosial, budaya demografi, lingkungan, pemerintah, teknologi dan kompetitor.
3. Strategi yang dapat diterapkan sebagai upaya pengembangan industri jamu di Kabupaten Bangkalan meliputi :

- Strategi mempertahankan dan meningkatkan kualitas produk

- Mempertahankan citra/image perusahaan

- Meningkatkan kegiatan promosi dan memperluas daerah pemasaran

- Mengembangkan kerjasama dengan industri lain diluar wilayah, dan

- Meningkatkan hubungan dengan pemerintah maupun lembaga lain.

4. Prioritas strategi yang dapat diterapkan industri jamu di Kabupaten Bangkalan meliputi :

1. Mempertahankan dan meningkatkan kualitas produk

2. Meningkatkan kegiatan promosi dan memperluas daerah pemasaran

3. Meningkatkan hubungan dengan pemerintah maupun lembaga lain

4. Mempertahankan citra/image perusahaan, dan

5. Mengembangkan kerjasama dengan industri lain diluar wilayah.

\section{SARAN}

1. Perlu adanya peningkatan terhadap kegiatan promosi dan perluasan daerah pemasaran sehingga industri-industri jamu di Kabupaten Bangkalan dapat bersaing dengan industri jamu diluar daerah Madura.

2. Perlu adanya kerjasama dengan pemerintah maupun lembaga lain untuk terus melakukan pembinaan dan pelatihan terhadap pengusaha-pengusaha industri jamu di Kabupaten Bangkalan. 


\section{DAFTAR PUSTAKA}

David, F. R. 2009. Manajemen Strategis. Jakarta: Penerbit Salemba Empat.

Disperindag. 2015. Direktori Industri Kecil dan Menengah Kabupaten Bangkalan s/d Tahun 2015. Bangkalan : Dinas Perijinan dan Perdagangan.

Geertz, H. 1981. Aneka Budaya dan Komunitas di Indonesia. Terjemahan A. Rachman Zainudin. Jakarta : FISUI.

Jauch, R. Lawrence \& Glueck, F. Wiliam. 1988. Manajemen Strategi dan Kebijakan Perusahaan (Ed. 3). Jakarta : Erlangga.
Nurmagribah, Mira. 2006. Strategi Pengembangan Usaha (Studi Kasus Pada Diana Bakery Kota Bekasi, Jawa Barat). Skripsi. Jakarta : Fakultas Sains dan Teknologi Universitas Islam Negeri Syarif Hidayatullah Jakarta.

Pali, Elisabet. 1994. Penjual Jamu Gendong. Tesis Master Program Pascasarjana. Bogor : Institut Pertanian Bogor. 